\title{
遠隔作業インタフェースとしての 背面投射型球面ディスプレイの開発*
}

\author{
藤本英 雄 ${ }^{* *}$ 佐 野 明 人** 関谷友孝 *** \\ Development of Rear-Projected Spherical Display for Interface of Teleoperation \\ Hideo FUJIMOTO, Akihito SANO and Tomoyuki SEKIYA

\begin{abstract}
Recently, many new potential uses of telerobotics and virtual reality have been explored in medical field. In order that a human operator can easily and intuitively execute the given micro operation, the development of suitable visual and haptic interfaces and the accurate registration of them are significantly important. However, these technical subjects are not easy to solve and have not been seriously considered. HMD is unsuitable for the surgical application because of its weight, restriction and narrow range of view. Recently, an immersive projection technology is drawing the attention for the virtual reality. In this paper, a compact and accessible spherical display with a stereo viewing system is discussed as an interface of teleoperation. The operator looks into the spherical display like a fortuneteller viewing a crystal ball. This environment is different from the immersive one surrounded by screens. The validity of developed system is confirmed by the experiment.
\end{abstract}

Key words: micro teleoperation, visual and haptic interfaces, rear-projected spherical display, stereo view, medical application

1.はじめに

近年，遠隔手術支援システムの研究が活発化している ${ }^{1)}$. 本 研究では, 人間の自然な作業動作に則した直感的操作が可能な 新しい操作環境の構築を狙い，遠隔手術などの微細作業のため のインタフェースについて険討している. 本論文では, 見回し ながら手元で行う作業に適した視覚提示装置について議論寸 る. 最近話題となっているIntuitive Surgical社の開発した daVinciでは，ミラーを使った光学的重ね合わせで，操作卓に 座った術者の手指に手術サイトの映像を投影し, EndoWrist と呼ばれるマニピュレータ先端部の直感的な操作を可能として (る2).このような手術支援システムのインタフェースとして は，高い操作性はもちろんのこと，既存の手術室への導入の観 点から，コンパクト性や可搬性が要求される.

人工現実感の世界では, 視覚提示装置として, 人間の頭部に 装着するHMD（Head Mounted Display）が知られている が，最近では人間を取り囲む空間をディスプレイに使用する着 想から，プロジェクション型没入ディスプレイが開発されてい る ${ }^{3)}$.たとえば，東京大学のCABIN ${ }^{4)}$ や岐阜県テクノプラザ のCOSMOSは，それぞれ5面，6面（含後方）のスクリーンで 取り囲んだ構造となっており，高精細プロジェクタで映像が投 影されている.これらは，高い没入感を与えることができ，周 りを見渡したりする都市計画などに応用されている。

HMDは, 重量, 拘束感, 視野角, 装置の着脱の煩雑さ, さ らに映像の提示部位などの観点から現実的ではない．また，プ ロジェクション型没入ディスプレイは, 装置全体が大きくなら ざるを得ないといった構造上の問題を抱えており，専用の部屋 を確保しなければならないほどである，また，微細作業は，基 本的に操作対象を周りから眺めることが多い5).CABINでは デジタルモックアップなどの応用例がこれに当たる。しかし，

\footnotetext{
* 原稿受付 平成13年5月18日

** 正会員名古屋工業大学工学部 (名古屋市昭和区御器所町)

*** 三洋テレコミュニケーションズ(株) (大東市三洋町 1-1)
}

このような場合，必ずしも仮想世界の中に身を置くような没入 感は必要ないのではと考えている。たとえば，川上ら ${ }^{6)}$ が開発 したMEDIA ${ }^{3}$ は，平面ディスプレイを直方体状に組み合わせ， その内部を仮想空間と想定し，観察者の位置に応じて各面に仮 想物体などを表示するシステムである.このシステムでは，手 にとってさまざまな方向から見回すことが可能なため，物体の 3次元形状の把握をより直感的かつ容易にすることができる.

本論文では，遠隔手術などの微細作業のためのインタフェー スとして，従来にはないタイプの背面投射型球面ディスプレイ の開発について述べる．2章では，通常使われる平面スクリー ンに対して，本研究で採用する球面スクリーン投影についてそ の特徴を述べる．3章では，開発した背面投射型球面ディスプ レイのプロジェクタおよびスクリーンについて説明する，4章 では，時分割方式の立体視を実現するためのメカニカルシャッ 夕の開発，同期回路の製作などについて述べる．5章では，立 位姿勢のマスタコンソールを示し，実際の投影実験からシステ 么の有效性を検証する。

\section{2. 球面スクリーン投影}

本研究では，図1に示すように，ローカルの現実世界の一部 にリモートの奏世界（一種の仮想世界） （应大）再現し，そ の仮想世界と向かい合う形での操作スタイルを考えている．ま た，操作者が仮想世界の対象に対して，外部の実世界から手術 器具などを想定したツールを使って操作することを念頭におい ている ${ }^{7)}$ 8)。これは，一種の複合現実感である ${ }^{9)}$.さらに， 作業性の観点から見回寸（ルックアラウンド）などの視点変更 を想定している (図2(a)参照)．将来的に，共同作業（コラボ レーション) のスタイルをとる場合は, 図2(b)に示すように, ディスプレイに複数のウィンドウを開くことが考えられる.

さて，平面スクリーン1面のみでは，見る角度により対象物 がフレームアウトする，この問題を回避するには，平面スク 
リーンを組み合わせる必要がある ${ }^{4)}$ ，一方，球面スクリーンで は原理的にフレームアウトを生じない，また，平面スクリーン を組み合わせた場合に生じる映像の継ぎ目の問題が回避でき， 連続的な表示面を確保することができる ${ }^{10)}$. スクリーンとの 距離は，眼の焦点調整の観点から重要となる．たとえば，観察 者とスクリーンとの距離が近づくと，眼の焦点調整の観点か ら，物体の距㕍が実際より近くに感じることがある．平面スク リーンの場合，見る角度により距離が変化し，さらに左右の眼 で距離が異なる. 一方, 球面スクリーンの場合, 左右の視点と 対応するスクリーン原点までの距離が等しく，さらに見る角度 が変わっても一定である.

これまでにも，球面（あるいは円筒面）スクリーンの開発例 がいくつかある.たとえば，筑波大学のEnsphered Vision, Elumens社のVisionStation ${ }^{11)}$ ，イメージ情報科学研究所が

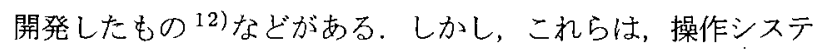
ムのインタフェースとしての捉え方はなされていない13).

球面投影における課題として，ボケや歪差が挙げられる.こ れらの問題を解決するには，特殊レンズなど光学系の設計を駆 使することが考えられる、VisionStationでは，レンズからの

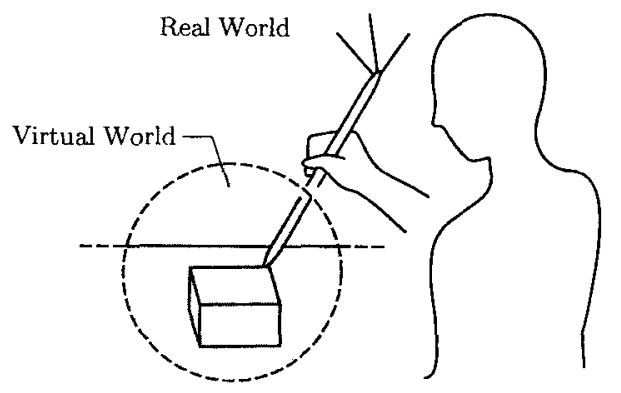

Fig.1 Micro teleoperation based on mixed reality

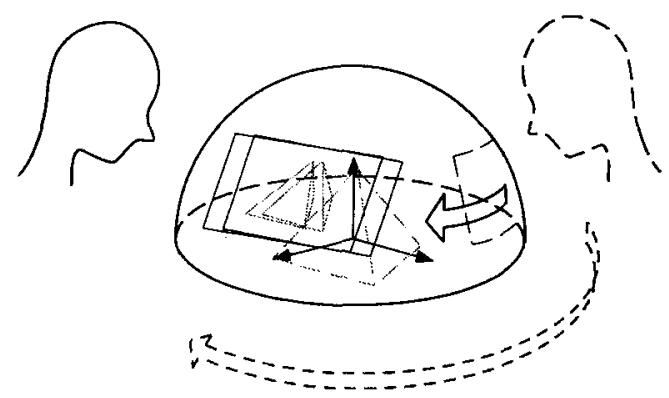

(a) Look-around

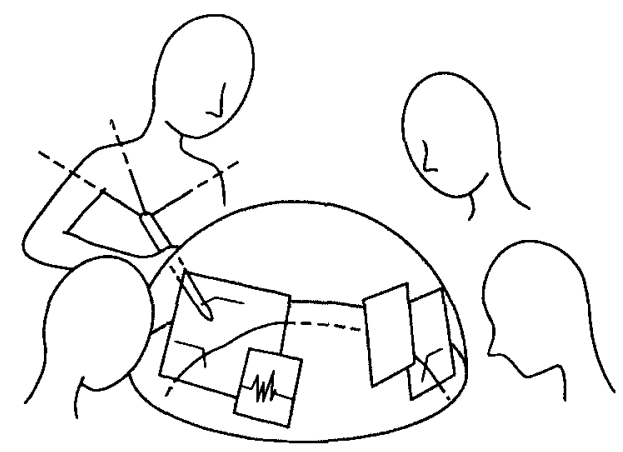

(b) Collaboration

Fig.2 Advantages of spherical display
距離によらず焦点が合う $180^{\circ}$ 無限焦点レンズを採用している. しかし，光学系の設計在行うことは，ノウハウや開発費の点か ら容易なことではない，そこで，本研究では，ソフトによる歪 補正を採用寸る. 近年のコンピュータの高速化から実時間制御 も可能である.

\section{3. 背面投射型球面ディスプレイ}

\section{1 背面投射}

マイクロドーム用に試作した背面投射型球面ディスプレイを 図3に示す，光学系を新たに組まずプロジェクタからの直接投 影によるシンプルな構造を採用した。さらに，時分割方式の立 体視を目指す，図1および図2のイメージを具体化させたもの で，球面ブィスプレイの外側に操作者である観察者がいる．ま た，投影方式として前面投射あるいは背面投射があるが，前面 投射であるとマスタツールや操作者自身によって影ができてし まい，映像が見られなくなってしまうため，必然的に背面投射 型となる ${ }^{14)}$. 結果的に，図3に示すような背面投射型球面ブィ スプレイは，従来にはないタイプとなっている。

本システムでは，描画処理にグラフィックスワークステーショ ンO2（MIPS R10000，195MHz）を用いる. O2には，SXGA （1280×1024）およびXGA $(1024 \times 768)$ の二つの解像度をサ ポートしたデュアルチャネル・ディスプレイ・オプションボー ドが搭載可能で，これに2台のプロジェクタが接続できる．ただ し, 実際は, 広带域 (150MHz) 分配器 (朋栄, HDA-101V) を介して2台の純正モニタとも接続する，なお，通常はスキャ ンコンバータを用いる方法が多い，

\section{2 液晶プロジェクタ}

プロジェクタにはCRT方式と液晶方式がある。近年の液晶 技術の進歩により，液晶プロジェクタの性能も年々高まって いる，画質や解像度，明るさといったものが従来のCRTプロ ジェクタと比べても迩色ないレベルになってきた，本システム では，プロジェクタに対して，以下に示すようないくつかの制 約がある10)。

（1）球面スクリーンに投影を行う場合，三管式では色ずれが 起きてしまうため，単眼式でなければならない。

（2）時分割方式による立体視を行う場合，垂直周波数が $120 \mathrm{~Hz}$ 耐えうるものでなければならない。

(3) プロジェクタ自体がコンパクトであること，さらに ローコストであることが望まれる。

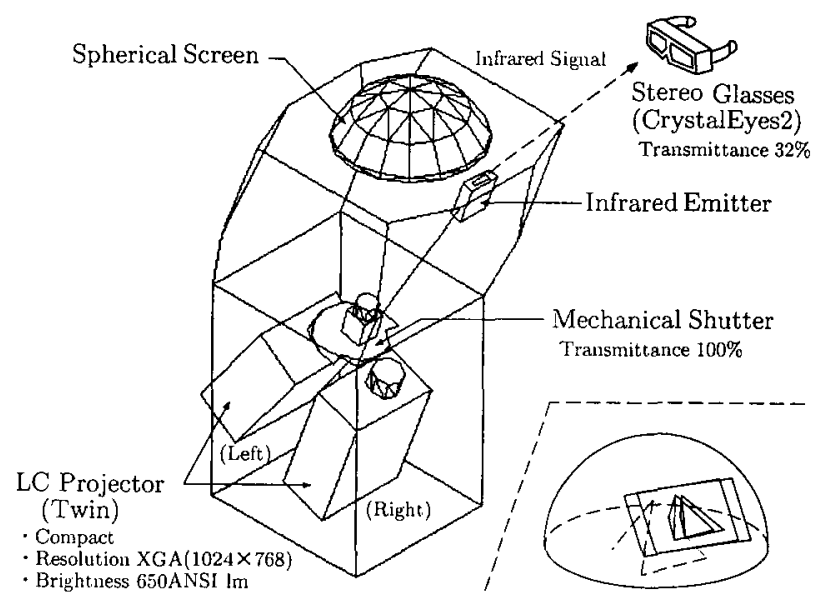

Fig.3 Rear-projection type spherical display 
(1)に関しては, 最近のCRT方式は明るさを追求することが主 流であるため，そのほとんどが三管式であり，単眼式は入手困難 である。これに対し液晶方式は単眼式である. (2)に関しては, CRT方式は垂直周波数 $120 \mathrm{~Hz}$ に対応寸るものが存在するが，液晶 方式には存在しない，これは液晶では残像が起きてしまうことが その要因である. (3)に関しては, CRT方式が大型であるのに 対し, 液晶方式は小型, 低価格のものが多数開発されている.

以上のことを考慮して，2台の液晶プロジェクタを使用し，同 期させたメカニカルシャッタと液晶シャッタ式メガネ (Stereo Graphics, CrystalEyes2) の組み合わせで立体視を実現する. 本システムでは, 液晶プロジェクタとして, ELP-7100（セイ コーエプソン）を選定し，XGAによる描画・投影を行う。な お, 立体視のための映像の時分割は，4章で詳細に述べる.

3.3 球面スクリーン

まず，一般的な平面スクリーンの構造を以下に簡単にまとめ ておく，背面投射では，透過型のスクリーンが用いられる．透 過型スクリーンは，観る側の反射率を低くしてあるため外光の 影響を受けにくく，前面投射のように部屋を暗く寸る必要がない． また，透過率が高く，加工しや寸いアクリルが使用されており， 指向性を広げるために，水平方向にはレンチキュラー（レンズ 状の凹凸加工），垂直方向には不純物による拡散が用いられる。 たとえば, レンズに近いほうから，フレネルレンズ+拡散板十 レンチキュラーレンズの順で並んだ 3 重構造を成している.

本研究では, 望みの球面スクリーンが入手不可能であったた め, 自作することとした. 球面スクリーンの場合, 平面の透過 型スクリーンのようにレンズ加工寸ることは困難あるいは不可 能であるため, 拡散剤だけを用いることとする. 拡散剤として 直径数十ミクロンのガラスビーズを使用し, 着色剂として白色 のラッカー系塗料を用いた，乳白色はどちらかと言えば照明用 であり，表示用にはコントラストをつけるためにブラウンある いはスモークが考えられるが, 実験の結果白色を選定した。

密着性の観点から, アクリルを供剂（接着剂）として用い, 拡散材および着色剂を混ぜ込み, 直径 $40 \mathrm{~cm}$ の透明な半球アク リル材の内側に吹き付ける. ただし, 供剤と拡散材との間に屈 折率の違いがないと拡散効果がなくなる.

\section{4. 立体視のための映像の時分割}

\section{1 メカニカルシャッタ}

時分割方式による立体視を実現するためには，立体視に必要 な左右眼用の画像を各プロジェクタで独立かつ常時投影し, 液 晶シャッタ式メガネの開閉と同期したシャッタをプロジェクタ 前面に配置寸ることになる。ここで，メガネと同じ液晶シャッ 夕を使用することが考えられるが ${ }^{13)}$, 通常, 液晶の透過率が 約 $30 \%$ と低いために, 液晶シャッタ式メガネと合わせた場合, 暗くなり過ぎる. そこで, 動作速度の点も考慮して, 本システ ムではメカニカルシャッタを新たに開発した。

液晶シャッタ式メガネCrystalEyes2では, 赤外線エミッタ から送信された信号 $(5 \mathrm{~V}-60 \mathrm{~Hz}$ の矩形波）を受信し，液晶 シャッタの切り替えを行っている. メガネとの同期のことを考 えると, 切り換えの時間を最小寸なわち一回転で一回シャッタ が切られる方が良いと判断し，スリットの数を一つとした，し たがって，回転数は3600 rpmとなる. 次に、シンプルでかつ 確実に動作することを考え, シャッタをダイレクトドライブす ることにした。サーボモータとして，3600rpmの回転が可能 で適用慣性モーメントが大きいという理由から， ACサーボ
モータEXE5750-S（オリエンタルモータ）を選定した. なお, 表1にFXE5750-Sの仕様を示す.

図4(a)に設計したメカニカルシャッタの外形を示す.まず, スリットの外側 (円周部) は不要と考え, 図のような形状を採 用した。さらに，スリット部を半円よりも少なく取ってある. これにより，一方の映像が完全に映らなくなってから，もう一 方の映像を徐々に映し出すことができる．これは，左右の映像 が重なって表示されないためである．次に，シャッタの直径に 関しては，少なくとも2台のプロジェクタのレンズ間距離は必 要である. 図4(b)のようにプロジェクタを重ねた場合にレンズ 間距離が小さくなり, 結果的にシャッタの直径を $22 \mathrm{~cm}$ に抑え ることができた

慣性モーメントを許容範囲内に収めるために, シャッタ本体

Table 1 Specifications of AC servo motor

\begin{tabular}{|c|c|c|c|}
\hline Rating Power & & W & 750 \\
\hline Rating Speed & & $\mathrm{rpm}$ & 3000 \\
\hline Maximum Speed & & $\mathrm{rpm}$ & 4500 \\
\hline \multirow[t]{2}{*}{ Load Inertia Moment } & $J$ & $\mathrm{kgm}^{2}$ & $13.5 \times 10^{-4}$ \\
\hline & $G D^{2}$ & $\mathrm{kgcm}^{2}$ & 54 \\
\hline
\end{tabular}

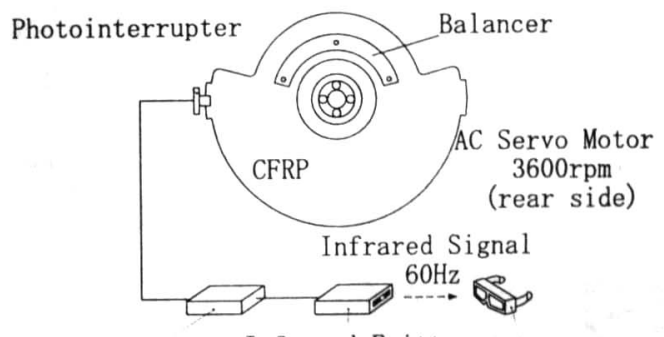

Pulse Generator

Infrared Emitter

Stereo Glasses

(a) Mechanical shutter and synchronization circuit

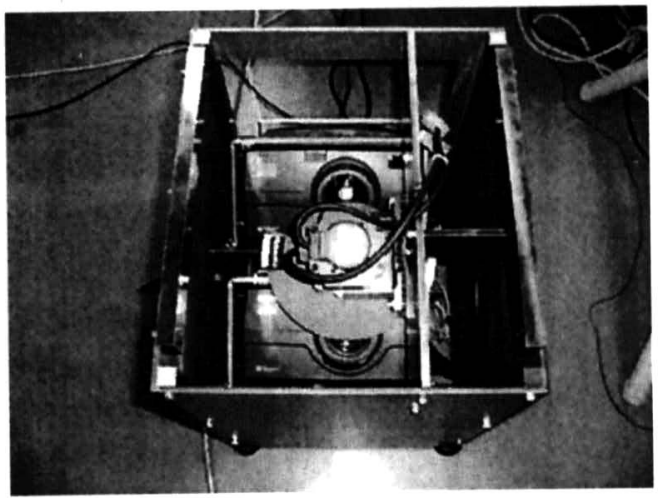

(b) Mechanical shutter and twin projectors

Fig.4 Mechanism of stereoscopic rear projection

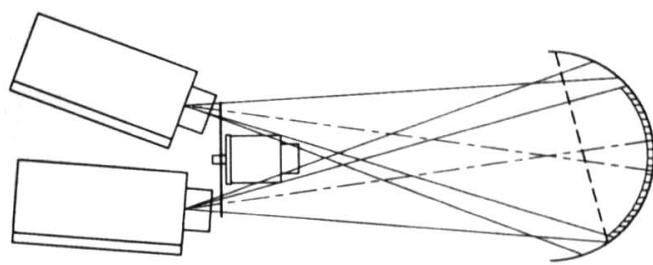

Fig.5 Arrangement of projectors, screen and mechanical schutter 
の材質をカーボンファイバ (CFRP) とし, 高強度・軽量化 を図った。厚みは1.5mmである、また，全周の遠心力が等し くなるようにバランサー (S45C) を取り付けた. メカニカル シャッタは, シャッタ本体，バランサー，ハウジングおよびポ ジロック（三木プーリ）で構成され, 最終的な慣性モーメント $\left(G D^{2}\right)$ は $19.7 \mathrm{kgcm}^{2}$ となった.

図5にプロジェクタ, 球面スクリーン, メカニカルシャッタ の配置を示す．光軸が球の中心を通るようにプロジェクタの角 度を設定してある. サーボモータは，2台のプロジェクタの光 路になるべく掛からないように配置されている，図からわかる ように, プロジェクタの配置から球面スクリーン上での二つの 投影面は若干上下にずれており，立体視では重なった領域（図 5 のハッチング部）しか使用しない.

\section{2 同期}

図4(a)に示すように，メカニカルシャッタに同期した，すな わち左右映像に同期したパルス発生器を製作した。図6にその 回路図とタイミングチャートを示す．まず，高速検出タイプの フォトインタラプタでメカニカルシャッタのトリガ信号を検出 した後, シュミットトリガで波形整形する. 次に，JKフリッ プフロップを使って, $120 \mathrm{~Hz}$ のパルス信号をデューティ比が

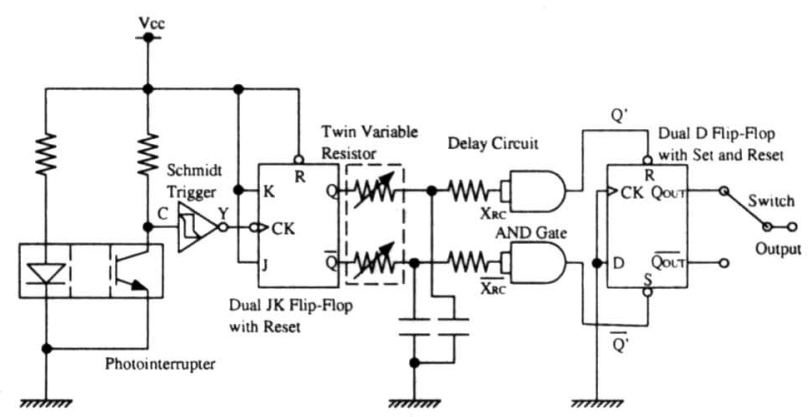

(a) Circuit diagram

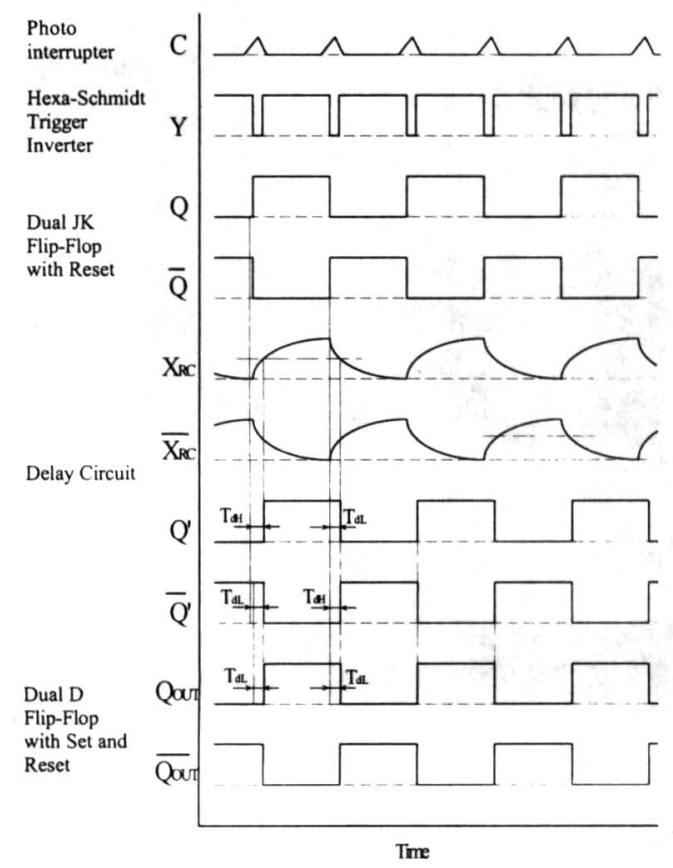

(b) Timing chart

Fig.6 Pulse generator for infrared emitter
1:1となるようにさらに波形整形を行う。結果的に，メカニカ ルシャッタが $3600 \mathrm{rpm}$ で回転した場合， $5 \mathrm{~V}-60 \mathrm{~Hz}$ の矩形波パ ルス信号が出力される.

次に, フォトインタラプタとプロジェクタレンズの配置（図 4 (a)参照) から, 出力波形の位相を約 $\pi / 2$ 遅らせる遅延回路を 組み込んだ. さらに, 遅延時間 $T_{d H}$ と $T_{d L}$ が一致(デューティ

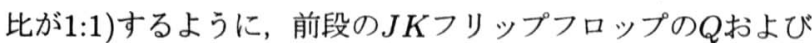
Qににそれぞれ遅延回路を接続した。 また，HからLへの遷移の 際の最大遅延時間を考慮し，Qと可の状態により，信号を反転 させる接続を行った，実験では，投影画像を観察しながら可変 抵抗 (ツインタイプ) により同期調整を図る。また，シャッタ の初期状態により切り替えが逆になる可能性があるので, 最終 段での信号の反転をスイッチで行えるようにした.

\section{5. マスタコンソールでの投影実験}

図7にマスタコンソールとそれに正対した操作者を示してい る. 操作系として, マスタデバイス (SensAble Technologies, PHANToM Desktop）をドーム脇のデッキに配置した. コン ソールの設計では, 液晶プロジェクタの焦点距離（90 cm以上） の制約から立位姿勢のコンソールを採用した．直径 $40 \mathrm{~cm}$ の球 面スクリーンは，上部 $2 / 3(13 \mathrm{~cm})$ がデッキから表出してい る.デッキまでの高さは $120 \mathrm{~cm}$ である.

本節では，目的どおりの投影性能を実現しているか簡単な実 験により確認する．提示可能な映像は，実世界のライブ映像 (遠隔作業用) およびCGで構筑した仮想世界（シミュレー ション・訓練用）である。なお，2台のCCDカメラ（ELMO， UN411）によって撮影された実映像は，2チャンネルのビデオ 信号としてマルチビューワ（朋栄, MV-10D）に送られて, 1 チャンネルのビデオ信号に圧縮された後 $\mathrm{O} 2$ に取り込まれる.

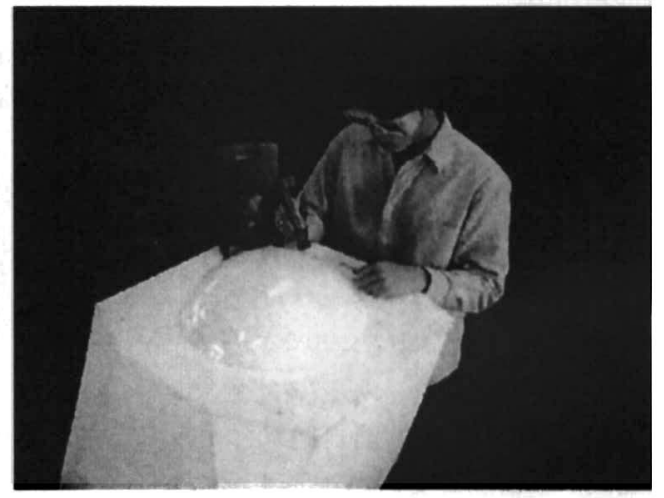

Fig.7 Master console and operation style

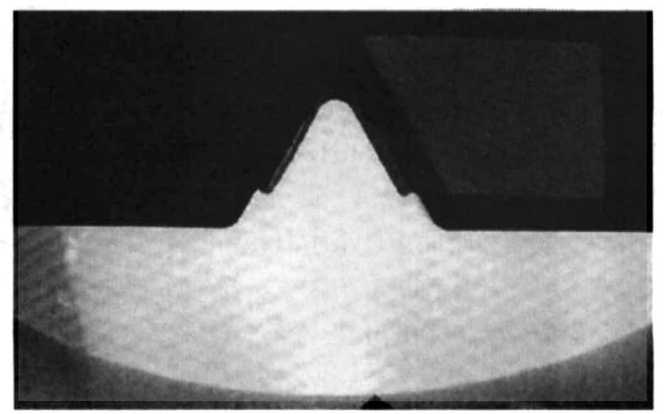

Fig.8 Images through stereo glasses 
実験では，左右別々の図柄を各CCDカメラで撮影し，これ を球面ディスプレイに提示する。図8はディスプレイを液晶 シヤッタ式メガネ越しに見た映像である. 図からわかるように, 球面ディスプレイには，左右の図柄が合成された映像が見て取 れる. 一方, 液晶シャッタ式メガネでは, 左右の図柄が正確に 分離されている，また，実用上問題ない明るさであった。した がって，これに歪み補正を施した左右眼用の映像を提示すれ ば，時分割方式の立体視が可能となる。

\section{6. 結 論}

本研究では，医療応用を念頭に置いた遠隔作業のためのイン タフェースとして，新しく背面投射型球面ディスプレイを開発 した。以下に得られた結果をまとめる。

(1) 微細作業は基本的に操作対象を周りから眺めるものであ る. HMDやスクリーンで囲まれた仮想世界の中に身を置く ような没入感ではなく，普段の現実世界の一部に仮想世界を (拡大) 再現し，その仮想世界と向か心合う形での操作スタ イルを提唱した。

（2）球面投影の有効性を示し，液晶プロジェクタによる背 面投影を採用した。特に，2台の液晶プロジェクタを使用し， 高精度に同期させたメカニカルシャッタと液晶シャッタ式メ ガネを組み合わせることで, 原理的に時分割方式での立体視 を可能とした. 球面スクリーンならずにメカニカルシャッタ を試作し，同期回路の設計を行った。

（3）コンパクトで作業し易いマスタコンソールを設計した。 球面ディスプレイは連続的な表示面が確保できるため, ルッ クアラウンドならびにコラボレーションなどでそのメリット を最大限活用することができる。

（4）投影実験の結果，液晶シャッタ式メガネでは，左右の図柄 が正確に分離された．したがって，今後，歪み補正を施した 左右眼用の映像を提示す机ば，時分割方式の立体視が可能と なる.また，実用上問題ない明るさであることを確認した。 (5) 開発したディスプレイシステムは遠隔作業に限定する ものではなく，今後, 映像提示装置としてユニークな利用法 が考えられる。
なお，本研究は，文部省科学研究費補助金平成8年度奖励研究 (A)(課題番号:08750312)拉よび平成10年度萌芽的研究(課題番 号:10875056)の援助を受けており，ここに謝意を表する。

\section{参 考 文 献}

1) 特集: 21 世紀の医療とロボティクス, 日本ロボット学会誌, 18, $1(2000) 1$.

2) G.S. Guthart and J.K. Salisbury: The Intuitive ${ }^{T M}$ Telesurgery System: Overview and Application, Proc. of the 2000 IEEE Int. Conf. on Robotics \& Automation, (2000) 618 .

3）特集: プロジェクション型没入ディスプレイ，日本バーチャルリ アリティ学会論文誌, 4, 3.(1999) 477.

4) 廣瀬通孝, 小木哲朗, 石綿昌平, 山田俊郎: 多面型全天周ディス プレイ(CABIN)の開発とその特性評価，電子情報通信学会論文 誌，D-II, J81-D-II, 5 (1998) 888.

5）光石衛，渡辺拓郎，中西泰文，浅井亮介，渡辺博義：テレ・マイ クロ・サージェリ・システムの試み，日本機械学会[No.95-17]口 ボティクス・メカトロニクス請演論文集， B，(1995) 1408.

6) 川上直樹, 稲見昌彦, 前田太郎, 舘: バーチャル・ホログラムの 手法によるメディアキューブの試作，日本バーチャルリアリティ 学会大会論女集, 1, (1996) 99.

7) 佐野明人, 藤本英雄, 関谷友孝, 楃野英紀: テレマイクロオぺ レーションのためのマイクロドームシステムの開発, 日本バー チャルリアリティ学会第4回大会論文集, (1999) 411.

8）佐野明人，藤本英雄，暒野英紀：造隔微細作業用マイクロドームシス テムの開発，精密工学会秋季大会学術講演会講演論文集，(1999) 28.

9) 田村秀行：複合現実：現実世界と仮想世界の融合、日本ロボット 学会誌, 16, 6 (1998) 759 .

10）岩田洋夫，橋本涉：背面投射球面ディスブレイ，Human Interface N \& R, 12, 2 (1997) 119.

11) http://www.elumens.com/

12）柴野伸之，畑中智行，中西弘泰，星野洋，長㴰龍一郎，澤田一哉，野 村淳二: 都市環境ヒューマンメディアにおける球面型没入ディス プレイ，日本バーチャルリアリティ学会論文誌，4，3 (1999) 549

13）山田俊郎, 小木哲朗, 㽦内大輔, 斎藤允, 広田光一, 廣瀬通孝: 触力賞提示装置のための傾斜3面ディスプレイの開発, 日本バーチャルリアリティ学会第5回大会論文集, (2000) 287.

14）矢野博明, 筧直之, 小木哲朗, 廣瀬通孝, 中垣好之: 多種触賞デ バイスに対応したHapticWorkBenchの開発，日本バーチャルリ アリティ学会論文誌, 4, 4 (1999) 723. 